\title{
Use of Aluminium Metal Embedded ThujaOccidentalis Leaves Carbon (AMETLC) for Fluoride Removal from Water: Equilibrium and Kinetic Studies
}

\author{
Dhilleswara Rao Vaddi ${ }^{*}$, Venkata Subba Rao Mushini' ${ }^{1}$, Phani Surya Muralikrishna \\ Mudumba ${ }^{2}$
}

${ }^{1}$ Department of Chemistry, G M R Institute of Technology, Rajam, affiliated to JNTUK- Kakinada, 532127, A.P, India ${ }^{2}$ Department of Chemistry, Government Polytechnic College, Thadepalligudem, West Godavari 534101, A.P, India

Received: 21/01/2020

Accepted: 27/04/2020

Published: 20/06/2021

\begin{abstract}
In this research work, Aluminum metal embedded Thuja Occidentalis leaves carbon (AMETLC) is used an adsorbent for the removal of fluoride from water. On batch technique, under key factors like $\mathrm{pH}$, the dosage of adsorbent, variation of fluoride concentration and contact time, $92 \%$ of fluoride removal is observed at room temperature under optimum experimental conditions with an adsorbent particle size of $<75 \mu \mathrm{m}$. The impact of existing negative ions on percentage removal of fluoride is studied, and it is noticed in the direction of $\mathrm{PO}_{4}{ }^{3-}>\mathrm{HCO}_{3}{ }^{-}>\mathrm{SO}_{4}{ }^{2-}>\mathrm{NO}_{3}{ }^{-}>\mathrm{Cl}^{-}$. The adsorbent is characterized by using FTIR, SEM, EDX, and XRD techniques. Experimental data reveal that the Langmuir isotherm model(maximum adsorption capacity obtained is $0.625 \mathrm{mg} \mathrm{g}^{-1}$ ) provided the best correlation $\left(\mathrm{R}^{2}=0.988\right)$ and is well fit followed by pseudo-second-order kinetic model represents mono-layered, and chemisorptions are the rate-determining step for fluoride adsorption. Thermodynamic studies reveals better adsorption is attained at lower temperatures. The standard free energy $\left(\Delta \mathrm{H}^{0}\right)$ is observed as negative and the negative value of standard free energy $\left(\Delta \mathrm{H}^{0}\right)$ represents that the adsorption process is exothermic. Moreover, desorption study reveals that fluoride leaching takes place at a pH 13.0. In addition, succinct cost estimation was done for the AMETLC which offered one of the best alternatives for the removal of fluoride. The application of AMETLC is helpful to decrease the fluoride concentration in groundwater samples to meet the permissible limit according to BIS-2012 standards.
\end{abstract}

Keywords: Thuja Occidentalis leaves, AMETLC, Defluoridation, Adsorption, SEM, FTIR

\section{Introduction}

Water is a universal and the most ample substance on earth [1]. For the endurance of most living things, particularly individuals, water is imperative component. The nature of water is one of the imperative worries for humankind since it is legitimately connected with human welfare [2].The people most particularly the rural tenants consume ground water without due thought of its biological and chemical composition. Maybe this might be because of tremendous water problems in parts of rural region [3]. Sufficient supply of clean and fresh water is a fundamental requirement for all human beings, yet a large number of individuals are denied of clean and fresh water and are compelled to allow polluted water. Out of various contaminants in the water, one of the most important contaminant is fluoride. Fluoride behaves as a ligand and quickly to form a significant number of various inorganic \& organic materials in rocks, air, soil, plants and animal creatures. Due to the solubility nature of these compounds, the surface and groundwater contain in the form of dissociated fluoride $\left(\mathrm{F}^{-}\right.$ ) ion. Fluorosis is imperative universal health trouble in 24 countries, which lies in the topographical fluoride belt that reaches out from Japan through Iraq, Turkey to China, Iran and Afghanistan. In India, around 20 million citizens were seriously influenced by fluorosis. The endemic fluorosis is prevalent in several states in India, such as Bihar, Haryana, Gujarat, Delhi, Karnataka, Maharashtra, Punjab, Tamil Nadu, Rajasthan, Uttar Pradesh, Telangana and Andhra Pradesh [4]. Fluoride in minute amount is a primary segment for bones and the development of dental veneer in a human being. Fluoride is a necessary nutrient for humankind at low levels. Fluoride in consumable water has both valuable and perilous for human wellbeing. In groundwater, if fluoride has low concentrations it helps to avoid the tooth rot in children. According to WHO, the desirable limit of $\mathrm{F}^{-}$in the potable water should be $<1.5 \mathrm{mg} \mathrm{l}^{-1}$ and according to BIS, the permissible limit of $\mathrm{F}^{-}$is $1.0 \mathrm{mg} \mathrm{l}^{-1}$ wherein alternative source the allowable limit is $1.5 \mathrm{mg}^{-1}$. Consumption of fluoride more than $8 \mathrm{mg} \mathrm{l}^{-1}$ in intake water for an extended period can cause skeletal deformities during teenage years [5], skeletal fluorosis [6], induces birth, immunological defects [7], arthritis, brittle bones and so on. Owing to these harmful effects on human beings, obligatory precautions must be taken to avoid the consumption of excess fluoride. Thus, there is a requirement for productive fluoride removal innovations that can be practically applied to water around the globe.

*Corresponding author: Dhilleswara Rao Vaddi, Department of Chemistry, G M R Institute of Technology, Rajam, affiliated to JNTUK- Kakinada, 532127, A.P, India. E-mail:dhilleswararao.v@gmrit.edu.in; Phone: 91-9553388641 
Numerous procedures have been account for expulsion of fluoride in water and the methods such as reverse osmosis, electrodialysis, membrane filtration, precipitation, ion exchange, electrocoagulation method [8]. These methods experience some drawbacks, and all-around acknowledged, basic, eco-accommodating and efficient techniques are as yet suggesting analysts. Adsorption [9] has been considered now as one of the most promising methods because, it is relatively simple, flexible, comfortable design, ease of operation and cost-effectiveness for removal of fluoride ion even in dilute solutions. In general, the adsorption mechanisms are associated with surface complexation, chemisorptions, diffusion through micropores, electrostatic interactions and ion-exchange [10]. Huge varieties of materials are available for the removal of fluoride as adsorbents. Adsorbents such as bio-Char [11], aluminium and iron oxide dispersed charcoals [12],etc. are used. Adsorbent such as activated carbon is a splendid adsorbent with better chemical properties as well as large surface area, high porous nature, more number of active sites for adsorption. The adsorption operational expenses are primarily controlled by the cost of the adsorbent, and hence there is a developing enthusiasm for searching for alternative antecedents (i.e., wastes) in activated carbon preparation. However, commercially available activated carbons are extremely expensive and hence activated carbon derived from agricultural wastes is used for the removal of fluoride. Some of the reported activated carbon materials such as activated carbon resulting from barks of Ficus racemosa [13], from bael (Aegle marmelos) shell [14], from cocos nucifera [15] etc., locally available materials such as, tree bark, seed, leaves, sawdust, activated carbon from groundnut husk [16, 17], chemically activated rice husk and corn cob activated carbon [18], activated bentonite etc. were used. To increase adsorption adequacy, the alteration of available carbon-based adsorbents with proper chemicals/substances has been researched with significant results [19], proposing that the prepared new adsorbents may remove fluoride ion successfully. This is due to fact that fluoride ion has a great affinity towards some metal ions such as $\mathrm{Al}^{3+}, \mathrm{Fe}^{3+}$, and $\mathrm{La}^{3+}$. Metal embedded in activated carbon material shows significant potential for defluoridation and is reported by Mondal et al. [20]. Thuja Occidentalis is indigenous to eastern North America and is grown in Europe as an ornamental tree. The leaves of Thuja Occidentalis are widely available in the underdeveloped regions $[21,22]$ and also in the study region and hence the activated carbon prepared from Thuja Occidentalis leaves can be utilized as a low-cost adsorbent or as a support for aluminium embedded for the adsorption of fluoride ion. Since, in this study region the literature shows that the amount of fluoride found to be high in groundwater samples [23]. Based on the thorough literature, this research paper is aimed to examine the study of the effectiveness of aluminium metal embedded to Thuja Occidentalis leaves carbon (AMETLC) as an adsorbent for the adsorption of fluoride ion from aqueous solutions. No literature is available on the utilization of Thuja Occidentalis leaves as an adsorbent for the removal of fluoride. As a result, AMETLC adsorbent is prepared and characterized by FTIR, X-ray diffraction, SEM and EDX for the surface morphology and used for studies of removal of fluoride through batch mode. The fundamental parameters considered are varying $\mathrm{pH}$, AMETLC dosage, time of contact period and varying fluoride ion initial concentration. Langmuir and Freundlich's models are considered to explain the equilibrium character of Fluoride adsorption onto the AMETLC adsorbent material. Kinetic studies are considered to know the removal efficacy of adsorbent, the removal mechanism of adsorption.

\section{Materials and Methods \\ 2.1. Plant Description}

Thuja Occidentalis leaves [24] are chosen for the preparation of activated carbon adsorbent material and which is a family of Cupressaceae. It is widely used as an ornamental plant; medicinally the leaf and leaf oil has been used for respiratory tract infections such as bronchitis, bacterial skin infections and hair preparations etc. Leaves of Thuja Occidentalis are widely available in the underdeveloped regions and also in the region under study.

\subsection{Preparation of aluminium metal embedded Thuja occidentalis leaves carbon (AMETLC)}

Leaves of Thuja Occidentalis are collected from our working place (rajam, Srikakulam district, Andhra Pradesh, India), and it is air-dried under sunlight around one week. The dried leaves are groundedinto a powder. Then the powder is treated with concentrated $\mathrm{H}_{2} \mathrm{SO}_{4}$ in a weight ratio of $1: 1.8$ (leave powder: sulphuric acid) [25,26] followed by heating $\left(160 \pm 5^{\circ} \mathrm{C}\right)$ on a hot plate at least for five hours and cooled to room temperature. The material is washed several times with triple deionised water until free of acid in the substance, and the resultant material is dried at a temperature $105 \pm 5{ }^{\circ} \mathrm{C}$. To the dried material of activated carbon material, aluminium metal powder is mixed in the weight ratio of 1:10 in a glass beaker followed by addition of concentrated $\mathrm{HCl}$ drop by drop with uniform stirring at $180 \mathrm{rpm}$ until the aluminium powder is thoroughly mixed with the activated carbon in order to form a precipitate [27]. The formed precipitate is washed with triple distilled water for many times until free of acid molecules. The $\mathrm{pH}$ of the resultant material shows neutral and is dried and grinds it into a required particle size of $<75 \mu \mathrm{m}$. Finally, it is stored in an airtight container.

\subsection{Preparation of synthetic fluoride solution}

Analytical reagent (AR) grade chemicals were utilized throughout the experimental procedure. Standard Stock fluoride (1000 $\left.\mathrm{mg} \mathrm{l}^{-1}\right)$ [0.5526 $\mathrm{g}$ of $\mathrm{NaF}$ salt was taken in a $1000 \mathrm{ml}$ volumetric flask and is dissolved with triple distilled water and makeup to the mark of the flask] was prepared with sodium fluoride salt. The intermediate fluoride solution (100 $\mathrm{mg} \mathrm{l}^{-1}$ ) was prepared from the $1000 \mathrm{mg} \mathrm{l}^{-1}$ stock solution by proper dilutions with triple distilled water. The standard fluoride solutions (6 to $22 \mathrm{mg} \mathrm{l}^{-1}$ ) are prepared from the intermediate fluoride solution by proper dilution with triple distilled water.

\subsection{Chemicals and instruments}

Analytical reagent grade aluminium powder is used for metal embedded to the carbon material. Ion analyser with fluoride electrode (Cyber Scan 2100, Eutech) was used for fluoride determination; $\mathrm{pH}$ meter (systronics, model 335) was used to measure the solution $\mathrm{pH} .0 .1 \mathrm{~N} \mathrm{HCl}$ and $0.1 \mathrm{~N} \mathrm{NaOH}$ solution were used to attuned the $\mathrm{pH}$ of the solution. The FTIR spectrum is recorded from 400 to $4000 \mathrm{~cm}^{-1}$ using a single beam, Perkin Elmer (Model BX FTIR) and anhydrous potassium bromide were used as a pellet material. Powder Xray diffraction was done on Panalytical Xpert Pro diffractometer with $\mathrm{CuK \alpha}$ radiation (1.5406 A). Scanning Electron Microscopic images were taken using SEM- Model Pilips XL30 equipped with an energy dispersive X-ray analyzer to study the surface morphology of the AMETLC and elemental composition analysis. The distinctive properties of AMETLC data are given in Table 1. 
Table 1: The distinctive properties of AMETLC

\begin{tabular}{ll}
\hline Parameter & Value \\
\hline$\%$ Moist & $6.2 \%$ \\
$\%$ ash & $13.4 \%$ \\
Total carbon & $64.33 \%$ \\
Matter soluble in water & $0.42 \%$ \\
Matter soluble in acid & $0.31 \%$ \\
Surface area $\left(\mathrm{m}^{2} / \mathrm{g}\right)$ & 76.3 \\
Pore volume $\left(\mathrm{cm}^{3} / \mathrm{g}\right)$ & 0.612 \\
$\mathrm{pH}_{\mathrm{zpc}}$ & 7.31 \\
\hline
\end{tabular}

\subsection{Batch Experiments}

In Batch mode experiments, $50 \mathrm{ml}$ of fluoride containing solution was takeninto a $250 \mathrm{ml}$ conical flask made up of plastic with a predetermined amount of AMETLC, and the solution $\mathrm{pH}$ was attuned to a specific value. The experimental solution was agitatedin an orbital shaker at $180 \mathrm{rpm}$ for a particular time interval. After that, the solution is filtered with Whatman filter paper using vacuum filtration pump, andthe leftover fluoride ions in the filtrate solution were determined by the fluoride-Ion selective electrode.In each performed experiment, one of the parameters was varied and remaining all parameters was fixed to a particular value in this adsorption studies. The influencing parameters, for instance, $\mathrm{pH}$ (3.0-9.0), adsorbent dosages (5- 30 $\mathrm{g} \mathrm{l}^{-1}$ ) of fluoride solution), time of contact (15-120 Minutes), initial fluoride concentration $\left(6-22 \mathrm{mg} \mathrm{l}^{-1}\right)$ are varied to get optimum adsorption conditions for the fluoride removal. The percentage removal $(\% \mathrm{R})$ and adsorbed quantity of fluoride at equilibrium ' $\mathrm{Q}_{\mathrm{e}}$ ' $\left(\mathrm{mg} \mathrm{g}^{-1}\right)$ are indicated by the following equations (1) and (2).

$\left.\% R=\left[\frac{C_{0}-C_{e}}{C_{o}}\right)\right] \times 100$

$Q_{e}=\left[\frac{C_{o}-C_{e}}{m}\right] \times V$

Here, ' $\mathrm{C}_{0}$ ' and ' $\mathrm{C}_{\mathrm{e}}$ 'be the concentrations of initial and equilibrium concentration of fluoride in $\mathrm{mg} \mathrm{l}^{-1}$, ' $\mathrm{m}$ ' is the amount of used adsorbent (g), and volume of fluoride solution is ' $\mathrm{V}$ ' in Liter.

\section{Results and Discussions \\ 3.1 Characterization of the AMETLC \\ 3.1.1 FTIR studies}

FTIR spectrum is generally used for structural information about adsorbent and gives information of a variety of functional groups present on the adsorbent surface. The functional groups present in adsorbent (AMETLC) is examined before and after defluoridation as shown in Figure 1. The FTIR band spectrum $2847 \mathrm{~cm}^{-1}$ and $2919 \mathrm{~cm}^{-1}$ before treated of an adsorbent is shifted to $2854 \mathrm{~cm}^{-1}$, and $2928 \mathrm{~cm}^{-1}$ in case of an adsorbent (AMETLC) is treated with fluoride solution, and the values belong to $-\mathrm{CH}_{2}$ stretching vibration band. Before adsorption, the FTIR band is noticed at $3417 \mathrm{~cm}^{-1}$ and that is shifted to 3421 $\mathrm{cm}^{-1}$ after treatment with fluoride solution represents $-\mathrm{OH}$ stretching vibration. In the case ofcarbon-carbon double bond $\left(\mathrm{C}=\mathrm{C}\right.$ ), the FTIR stretching band is at $1613 \mathrm{~cm}^{-1}$ (before adsorption) and is shifted toward a value $1621 \mathrm{~cm}^{-1}$ in the treated adsorbent. The vibration band at $1169 \mathrm{~cm}^{-1}$ (before adsorption) is shifted to $1198 \mathrm{~cm}^{-1}$ (after adsorption), and this fits $\mathrm{C}-\mathrm{O}$ stretching vibration in alcohol. However, these vibration values have merely marginal shifts representing that the adsorption process existing between the AMETLC adsorbent and the fluoride ion usually is electrostatic.

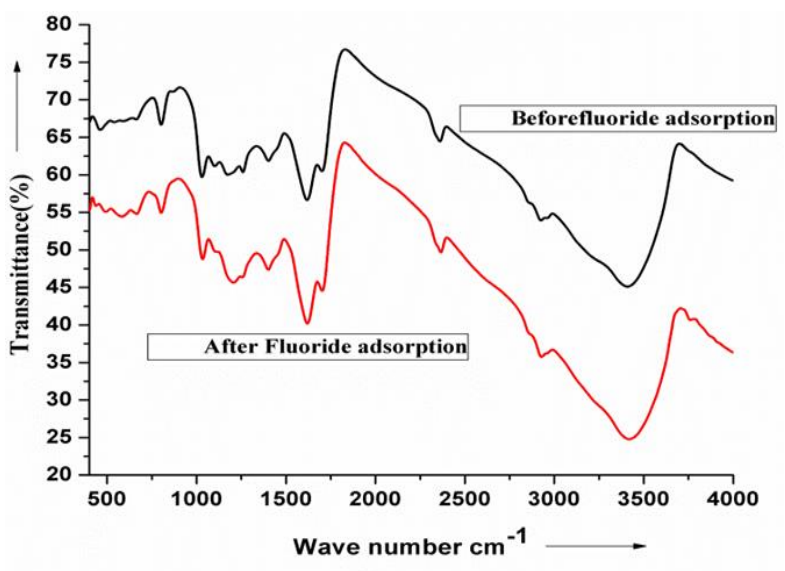

Figure 1: FTIR Spectra of AMETLC before and after defluoridation

\subsubsection{SEM studies}

SEM pictures of AMETLC before (a, b) as well as after (c, d) fluoride adsorption treatment appear in Figure 2, with different magnifications. In the SEM micrographs, the untreated sample showed small particles agglomerated to result in a more prominent structure with porous nature. The treated sample also showed a similar structure but with more or less similar porosity. The slight changes in morphology might be ascribed to the adsorption and exchange of fluoride with inorganic layerslike $\alpha-\mathrm{Al}_{2} \mathrm{O}_{3}, \mathrm{AlCl}_{3} \& \mathrm{Al}(\mathrm{OH})_{3}$ and so on the adsorbent surface of AMETLC.

\subsubsection{EDX studies}

The EDX analysis of AMETLCis shown in Figure 3, along with elemental composition. The peaks in EDX show the existence of components carbon, oxygen, aluminium, chlorine and sulphur. The signal peaks highlighted the existence of large percentages of carbon and oxygen in both the untreated as well as fluoride-treated samples. Chlorides, as well as aluminium, are additionally present however in a lesser amount than carbon and oxygen. The intensity of the fluoride $\left(\mathrm{F}^{-}\right)$peak is higher in sample when treated by a fluoride solution but could not be observed in the untreated sample. The oxygen and chloride percentage in the untreated sample is higher than the treated sample. Some fluoride ions are trapped on the surface of the adsorbent material after adsorption. This might be because of the substitution of some oxygen and chloride containing groups of adsorbent by fluoride on the surface of the adsorbent, in the treated sample.

\subsubsection{XRD studies}

The powder XRD patterns of adsorbent AMETLC before as well as after fluoride adsorption appear in Figure 4. The Patterns showed broad background which indicates that a significant portion of the adsorbent sample is amorphous. There are few sharp peaks also which might be due to some minor crystalline part within the sample. The peaks (d-lines) observed at $2 \theta$ values of $24.95,30.87,38.19,40.37,51.87,56.07$ correspond to the crystalline regions present on the amorphous adsorbent. The peaks at $24.95 \& 30.87$ are attributed to $\alpha$ $\mathrm{Al}_{2} \mathrm{O}_{3}, \mathrm{AlCl}_{3}$ respectively while the peak at 38.19 corresponds to $\mathrm{Al}$ metal [20]. The peak at $2 \theta$ value of 51.87 is likely due to $\mathrm{Al}(\mathrm{OH})_{3}$. Thus the AMETLC is partly covered with the crystalline parts of $\alpha-\mathrm{Al}_{2} \mathrm{O}_{3}, \mathrm{AlCl}_{3} \& \mathrm{Al}(\mathrm{OH})_{3}$ and their amorphous counterparts might also be present in the adsorbent. 

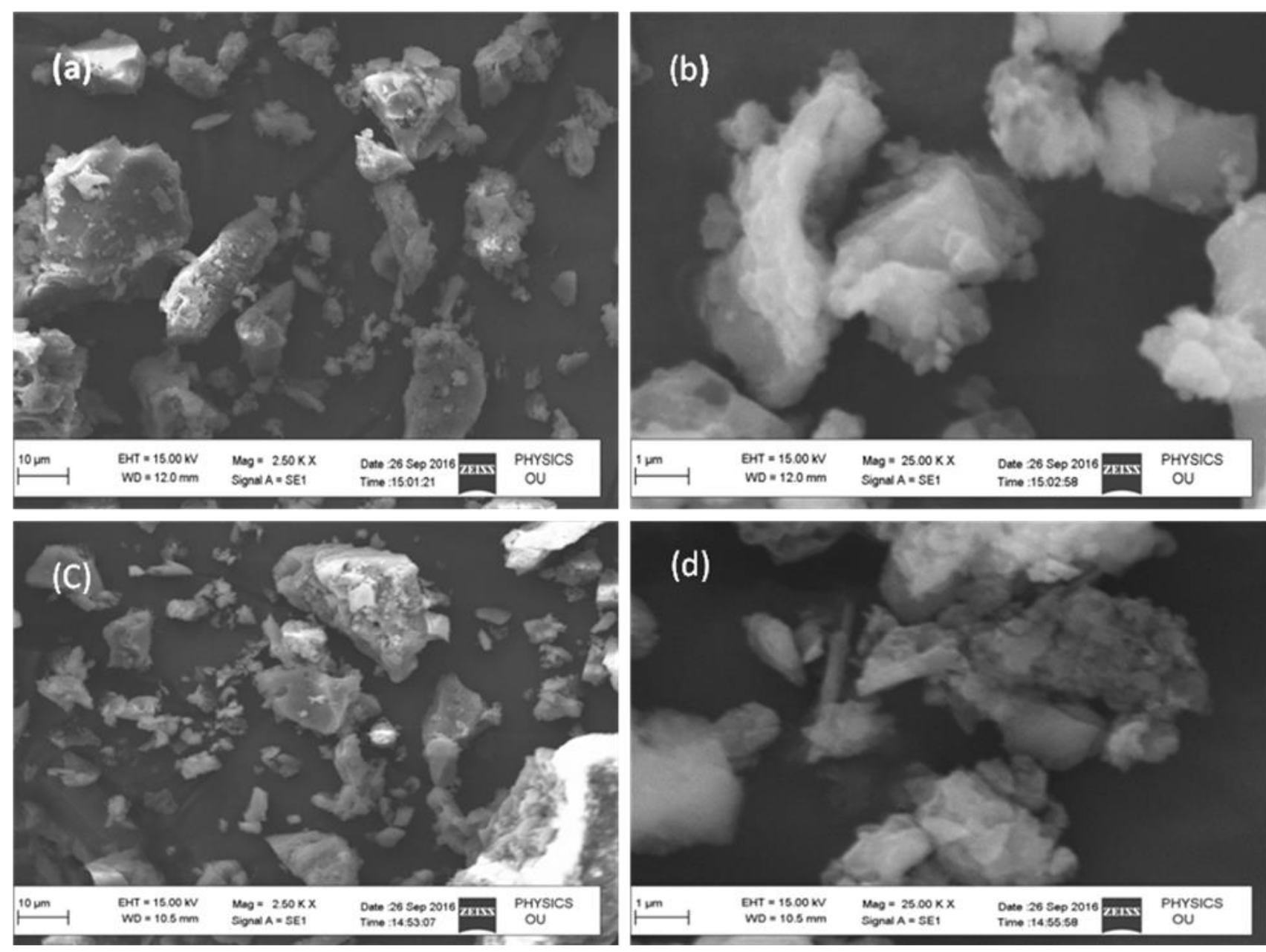

Figure 2: SEM pictures of AMETLC before (a,b) and after (c,d) fluoride adsorption

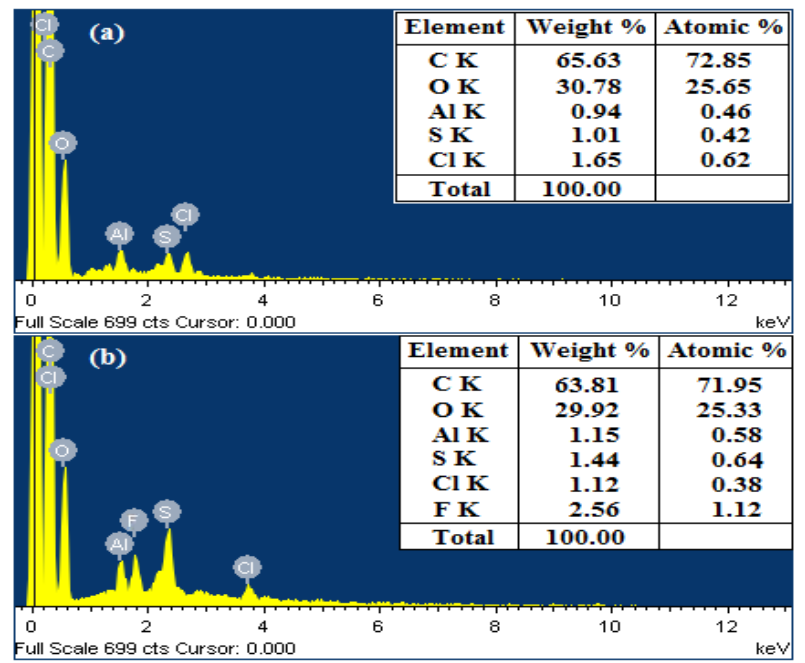

Figure 3: EDX Spectra of AMETLC before and after fluoride adsorption

The highly amorphous nature of treated sample provides more active sites for fluoride adsorption while the crystalline $\alpha-\mathrm{Al}_{2} \mathrm{O}_{3}, \mathrm{AlCl}_{3} \& \mathrm{Al}(\mathrm{OH})_{3}$ particles also facilitate the exchange of $\mathrm{F}^{-}$ion, with overall better adsorption of fluoride for the treated sample. The crystal size is obtained as $17.33 \mathrm{~nm}$.

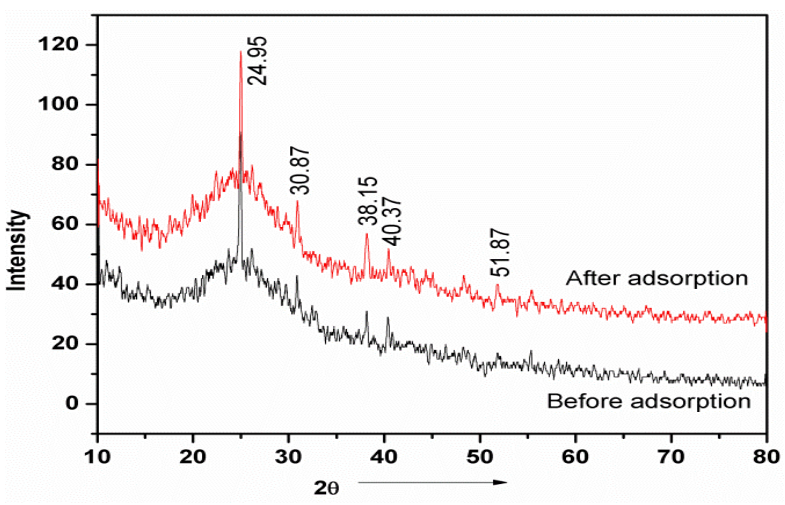

Figure 4: XRD patterns of AMETLC before as well as after fluoride adsorption

\subsubsection{Point of Zero Charge ( $\mathrm{pH}_{p z c}$ )}

The zero point charge of AMETLC is determined to know the charge of the adsorbent surface [28]. To determine the $\mathrm{pH}_{\mathrm{zp}}$ of AMETLC, make $0.01 \mathrm{M} \mathrm{KNO}_{3}$ solution. Take $25 \mathrm{~mL}$ of $0.01 \mathrm{M} \mathrm{KNO}_{3}$ solution in to ten different Erlenmeyer flasks. The $\mathrm{pH}$ of the each solution was adjusted to 2.0 to 11.0 by adding $0.1 \mathrm{M} \mathrm{HCl}$ or $0.1 \mathrm{M} \mathrm{NaOH}$ solutions. Add $25 \mathrm{mg}$ of AMETLC into the each flask containing $\mathrm{KNO}_{3}$ solution and shake the contents for 48 hours and the final $\mathrm{pH}$ of the solution is measured. The difference in the final $\mathrm{pH}$ and initial $\mathrm{pH}$ was noted. A graph plot between $\mathrm{pH}_{\mathrm{ivs}}\left(\mathrm{pH}_{\mathrm{f}}-\mathrm{pH}_{\mathrm{i}}\right)$ gives a curve from where the $\mathrm{pH}_{\mathrm{zpc}}$ for AMETLC is determined as the point at which the curve of $\mathrm{pH}_{\mathrm{i}}$ vs $\left(\mathrm{pH}_{\mathrm{f}}-\mathrm{pH}_{\mathrm{i}}\right)$ crosses the $\mathrm{x}$-axis was 
known as $\mathrm{pH}_{\mathrm{zpc}}$ of AMETLC. The experimental result showed that $\mathrm{pH}_{\mathrm{zpc}}$ (zero point charge) of AMETLC is obtained as 7.31 as shown in Figure 5.This indicates that AMETLC adsorbent surface is positively charged below 7.31 and negatively charged above 7.31

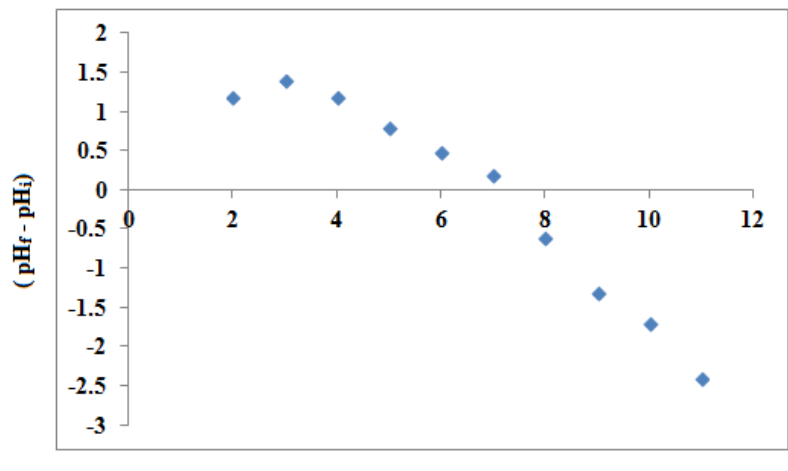

$\mathrm{pH}_{\mathrm{i}}$

Figure 5: Point of Zero charge of AMETLC

\subsection{Adsorption studies}

\subsubsection{Effect of $\mathrm{pH}$}

The solution $\mathrm{pH}$ has a major impact on the expulsion of fluoride ions because it decides the surface charge of the adsorbent. So as to establish the impact of $\mathrm{pH}$ on the adsorption of $\mathrm{F}^{-}$ions, the batch equilibrium examinations at various $\mathrm{pH}$ values were carried out from $3.0-9.0 \mathrm{pH}$ by predetermined concentration of fluoride $\left(10 \mathrm{mg} \mathrm{l}^{-1}\right)$, adsorbent dosage $\left(20 \mathrm{~g} \mathrm{l}^{-}\right.$ $\left.{ }^{1}\right)$ of fluoride solution) and time of contact 90 minutes. The experimental result showed that $\mathrm{pH}_{\mathrm{zpc}}$ (zero point charge) of AMETLC is obtained as 7.31. This indicates that AMETLC adsorbent surface is positively charged below 7.31 and negatively charged above 7.31 [29]. The efficiency of the expulsion of fluoride and the amount of fluoride uptake at different $\mathrm{pH}$ conditions are shown in Figure 6(a). Itis noticeable that the adsorption of $\mathrm{F}^{-}$is most apparent at the $\mathrm{pH}$ of 3.5 and hence maximum $\mathrm{F}^{-}$removal takes place at $\mathrm{pH} 3.5$ which is below $\mathrm{pH}_{\mathrm{zpc}}$ of AMETLC. At the $\mathrm{pH}$ of 3.5, the surface of the AMETLC will be positively charged as a result, there is a higher possibility of columbic interaction between $\mathrm{F}^{-}$ion and the aluminium metal embedded carbon surface [20]. As the $\mathrm{pH}$ increases from 3.5 to 9.0 the adsorption of fluoride decreases, since the number of surface sites is negatively charged and hence more electrostatic repulsions arises. Additionally, similar kind of interaction is reported by Junlian [30] and recommended thatadsorption of $\mathrm{F}^{-}$takes place through innersphere surface complexes with the surface hydroxyl groups as shown in equations (3) to (6).

$=\mathrm{Al}-\mathrm{OH}+\mathrm{H}^{+} \rightarrow=\mathrm{Al}-\mathrm{O}^{+} \mathrm{H}_{2}$

$=\mathrm{Al}-\mathrm{O}^{+} \mathrm{H}_{2}+\mathrm{F}^{-} \rightarrow=\mathrm{Al}-\mathrm{O}^{+} \mathrm{H}_{2} \cdots \mathrm{F}^{-}$

$=\mathrm{Al}-\mathrm{O}^{+} \mathrm{H}_{2}+\mathrm{F}^{-} \rightarrow \mathrm{Al}-\mathrm{F}+\mathrm{H}_{2} \mathrm{O}$

$=\mathrm{Al}-\mathrm{OH}+\mathrm{F}^{-} \rightarrow=\mathrm{Al}-\mathrm{F}+\mathrm{OH}^{-}$

\subsubsection{Effect of adsorbent dosage}

The adsorption studies are carried out with varying of adsorbent (AMETLC) amount in between $5 \mathrm{~g}$ to $30 \mathrm{~g} \mathrm{l}^{-1}$ of $\mathrm{F}^{-}$ solution by maintaining other parameters remains constant such as the concentration of $\mathrm{F}^{-}\left(10 \mathrm{mg} \mathrm{l}^{-1}\right), \mathrm{pH}$ (3.50) and time of contact (90 minutes) for all samples. When the AMETLC adsorbent dosage increases, the adsorption of $\mathrm{F}^{-}$ions on the AMETLC adsorbent surface also increases, since there is an increment in the amount of binding sites. However, further increment in the amount of AMETLC dosage does not have a substantial increment in the expulsion of fluoride ion due to the number of fluoride ions remains constant with an adsorbent after to reach of effective equilibrium. However, the fluoride uptake ' $\mathrm{Q}_{\mathrm{e}}$ ' $\left(\mathrm{mg} \mathrm{g}^{-1}\right)$ on the surface decreases from $0.800 \mathrm{mg} \mathrm{g}$ ${ }^{1}$ to $0.308 \mathrm{mg} \mathrm{g}^{-1}$, as the AMETLC adsorbent dosage increased from 5 to $30 \mathrm{~g} \mathrm{l}^{-1}$ of fluoride solution (Figure 6(b)), because the number of $\mathrm{F}^{-}$ions is fixed to adsorb on the AMETLC surface. Based on this examination, the adsorbent dosage of AMETLC $20 \mathrm{~g} \mathrm{l}^{-1}$ of $\mathrm{F}^{-}$solution is taken as fixed for further studies.

\subsubsection{Effect of contact time}

Equilibrium time stands another significant factor in adsorption studies. The experiment is performed under optimum conditions of $\mathrm{pH}$ (3.50), the adsorbent amount (20 g $\mathrm{l}^{-1}$ of $\mathrm{F}^{-}$solution) and initial $\mathrm{F}^{-}$ion concentration $\left(10 \mathrm{mg} \mathrm{l}^{-1}\right)$ by changing the period of contact from 15 to 120 minutes. The obtained results (Figure 6(c)) indicate that defluoridation increases by increasing time and finally attains saturation at 90 minutes. The adsorption of fluoride is rapid in before 90 minutes. This might be the number of active sites are present initially on the AMETLC surface. The expulsion rate of fluoride is practically insignificant afterwards the attainment of equilibrium and the reason behind is quick exhaustion of the adsorbing sites.

\subsubsection{Effect of concentration of Fluoride Ion}

The percentage removal of $\mathrm{F}^{-}$is mostly dependent on the initial fluoride concentration. Under optimum $\mathrm{pH}$ (3.50), time of contact (90minutes) and amount of AMETLC adsorbent (20 $\mathrm{g} \mathrm{l}^{-1}$ of $\mathrm{F}^{-}$solution), the adsorption study is investigated by varying of fluoride ion concentration from 6.0 to $22.0 \mathrm{mg} \mathrm{l}^{-1}$. The investigational results (Figure 6(d)) clearly indicate that at $10 \mathrm{mg} \mathrm{l}^{-1}$ of the $\mathrm{F}^{-}$concentration the maximum uptake of fluoride ions on to the surface of AMETLC is $0.426 \mathrm{mg} \mathrm{g}^{-1}$. It is observed that less number of fluoride ions(low concentration) immediately interact with binding sites available on the adsorbent and facilitates $100 \%$ adsorption while number of fluoride ions increases in solution (increasing concentration) the specific binding sites are saturated therefore no more sites are available and exchange sites getting almost filled. This shows that energetically lower numbers of favourable binding sites are involved with in.

\subsubsection{Effect of agitation speed}

The effect of agitation speed on removal efficiency of fluoride was studied by varying the speed of agitation from 90 rpm $250 \mathrm{rpm}$. The adsorption studies are carried out with varying of $\mathrm{rpm}$ of the fluoride solution with an adsorbent (AMETLC) amount of $20 \mathrm{~g} \mathrm{l}^{-1}$ of $\mathrm{F}^{-}$solution by maintaining other parameters remains constant such as the concentration of $\mathrm{F}^{-}\left(10 \mathrm{mg} \mathrm{l}^{-1}\right), \mathrm{pH}$ (3.50) and time of contact (90 minutes) for all samples. When the rpm of agitated solution increases from 60 to $180 \mathrm{rpm}$ the adsorption of fluoride increases slowly and further increase of rpm the adsorption of $\mathrm{F}^{-}$ions on the AMETLC adsorbent surface decreases, hence the rpm was fixed to $180 \mathrm{rpm}$ throughout the experimental process. 


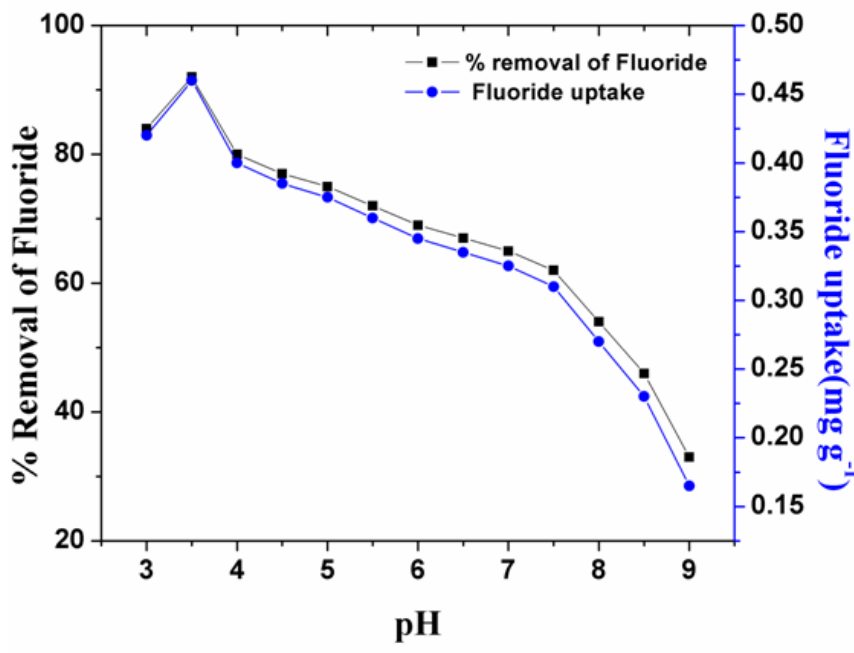

(a) Effect of $\mathrm{pH}$ on \% removal of fluoride and fluoride uptake ' $\mathrm{Q}_{\mathrm{e}}$ ' $\left(\mathrm{mg} \mathrm{g}^{-1}\right)$

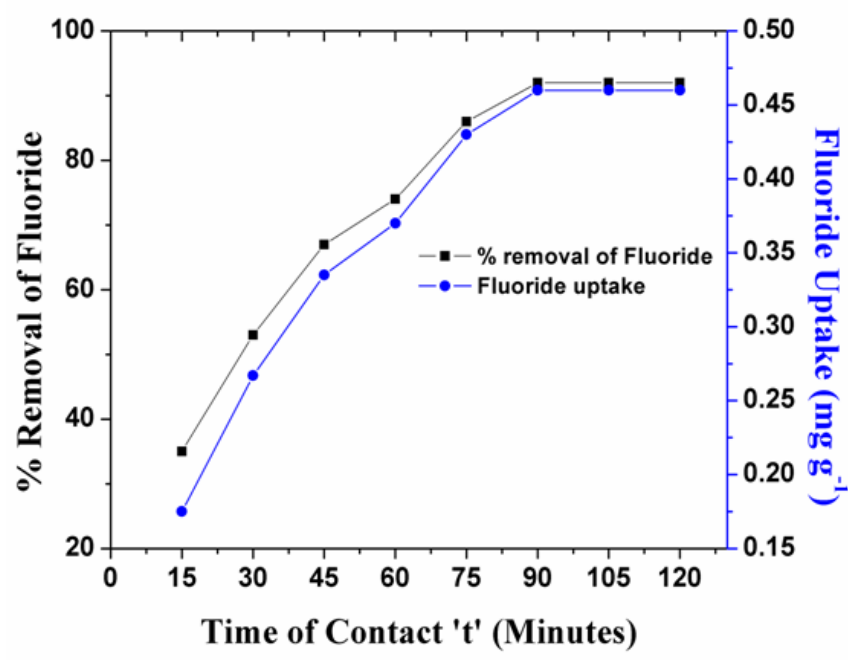

(c) Effect of time of contact on \% removal of fluoride and fluoride uptake ' $Q \mathbf{t}$ ' $\left(\mathrm{mg} \mathrm{g}^{-1}\right)$

Figure 6: Parameters affecting \% removal of $\mathrm{F}^{-}$and $\mathrm{F}^{-}$uptake $\left(\mathrm{mg} \mathrm{g}^{-1}\right)$ using AMETLC, the effect of 6(a): pH, 6(b): AMETLC dosage, 6(c): contact period, $6(\mathrm{~d})$ : initial $\mathrm{F}^{-}$concentration.

\subsection{Adsorption Isotherms}

The adsorption isotherm method is useful for demonstrating suitable conditions in the area of adsorption studies. The isotherm depicts the connection between's equilibrium amounts of solute on the adsorbent material and plays an indispensable role in predicting the adsorption limit of the adsorbent. The adsorption mechanism of $\mathrm{F}^{-}$on to the material (adsorbent) is contemplated using Freundlich and Langmuir adsorption Isotherms. The lineralized type of the two models and calculated adsorption isotherm parameters are represented in Table 2 . The respective adsorption isotherm graphs are shown in Figure7. The most considerable features of Langmuir isotherm is defined by dimensionless constant

$R_{L}=\frac{1}{1+b C_{o}}$

where, ' $\mathrm{C}_{\mathrm{o}}$ ' represents the initial concentration of $\mathrm{F}^{-}$ion $\left(\mathrm{mg} \mathrm{l}^{-}\right.$ $\left.{ }^{1}\right)$ and ' $\mathrm{K}_{\mathrm{L}}$ ' represents the Langmuir constant. According to Masoud et.al [31] they said that adsorption is favorable or not depending upon the following conditions like positive $\left(R_{L}=0\right.$ $\left.<\mathrm{R}_{\mathrm{L}}<1\right)$, linear $\left(\mathrm{R}_{\mathrm{L}}=1\right)$, un-positive $\left(\mathrm{R}_{\mathrm{L}}>1\right)$ or irreversible $\left(\mathrm{R}_{\mathrm{L}}\right.$ separation factor ' $\mathrm{R}_{\mathrm{L}}$ ',

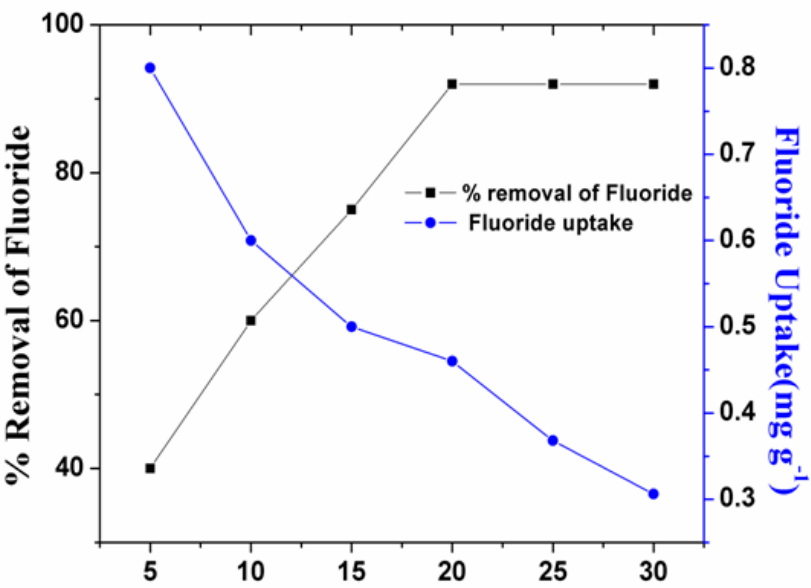

Adsorbent Dosage $\left(\mathrm{g} \mathrm{I}^{-1}\right)$

(b) Effect of adsorbent dosage on \% removal of fluoride and fluoride uptake ' $Q_{\mathrm{e}}$ ' $\left(\mathrm{mg} \mathrm{g}^{-1}\right)$

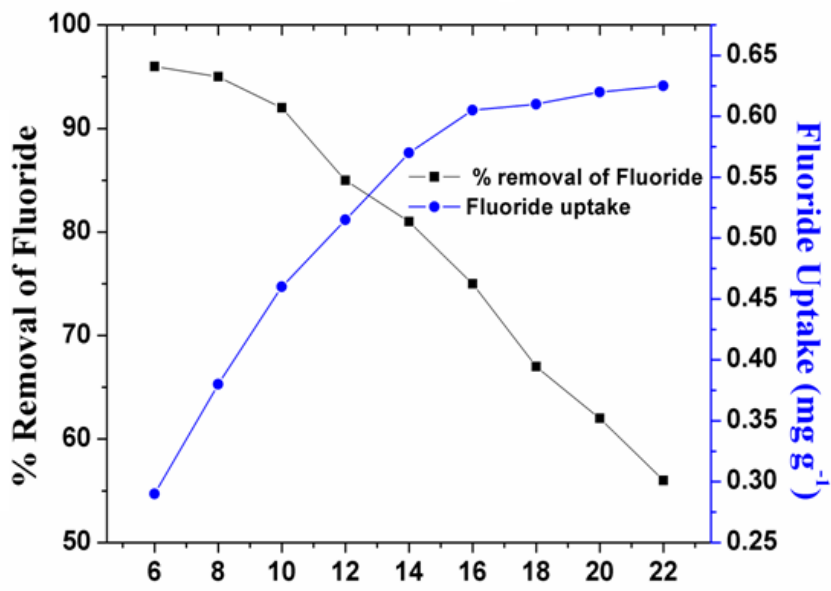

Initial Concentration of Fluoride $\left(\mathrm{mg} \mathrm{I}^{-1}\right)$

(d) Effect of initial concentration of fluoride on \% removal of fluoride and fluorideuptake ' $\mathrm{Q}_{\mathrm{e}}$ ' $\left(\mathrm{mg} \mathrm{g}^{-1}\right)$
$=0$ ). In the present work, the $R_{L}$ value is 0.023 which is not as much as unity shows the idealness of the adsorption process for removal of $\mathrm{F}^{-}$ion. Moreover, $\mathrm{R}^{2}$ value $(0.988)$ in Langmuir model is greater than Freundlich model $\left(\mathrm{R}^{2}=0.928\right)$, and thus adsorption is all around characterised by Langmuir display and finally concluded that the AMETLC surface is homogeneous and the procedure is unilayered [13].

\subsection{Kinetic Adsorption Isotherms}

Kinetic model is usually used to explain the adsorption mechanism. The kinetics of any adsorption procedure is a function of various parameters, for example, adsorbateadsorbent interactions, the concentration of adsorbate, structural properties of the adsorbent with a particular ultimate objective to clear up the adsorption kinetics of $\mathrm{F}^{-}$by AMETLC adsorbent, four kinetic adsorption models, for instance, pseudofirst-order and second-order, intra-particle diffusion and Elovich models are studied. The linearized forms of the kinetic models and determined kinetic constants are presented in Table 2. The individual kinetic adsorption graphs of the four models are shown in Figure 8. 
Table 2: Adsorption Isotherm Data of Freundlich and Langmuir and Kinetic adsorption data

\begin{tabular}{|c|c|c|c|c|c|}
\hline $\begin{array}{l}\text { Adsorption Isotherm } \\
\text { Model }\end{array}$ & Linear form & Graph & $\mathbf{R}^{2}$ & Parameters & $\begin{array}{l}\text { Obtained } \\
\text { Value } \\
\end{array}$ \\
\hline \multirow{2}{*}{ Langmuir Model } & $\begin{array}{lll}1 & 1 & 1\end{array}$ & \multirow{2}{*}{$\frac{1}{C_{e}} v s \frac{1}{Q_{e}}$} & \multirow[b]{2}{*}{0.988} & $\mathrm{~b}$ & 4.2480 \\
\hline & $\overline{\mathrm{Q}_{\mathrm{e}}}=\overline{\mathrm{Q}_{\max } \mathrm{bCe}}+\overline{\mathrm{Q}_{\max }}$ & & & $\mathrm{R}_{\mathrm{L}}$ & 0.023 \\
\hline \multirow{2}{*}{ Freundlich Model } & \multirow{2}{*}{$\ln \mathrm{Q}_{\mathrm{e}}=\ln K_{f}+\frac{1}{n_{f}} \ln \mathrm{C}_{\mathrm{e}}$} & \multirow{2}{*}{$\ln C_{e} v s \ln Q_{e}$} & \multirow{2}{*}{0.928} & $\mathrm{~K}_{\mathrm{f}}$ & 0.4434 \\
\hline & & & & $1 / \mathrm{n}_{\mathrm{f}}$ & 0.190 \\
\hline \multicolumn{6}{|c|}{$\begin{array}{l}\text { Equilibrium concentration of } F^{-} \text {represents ' } \mathrm{C}_{\mathrm{e}} \text { ', } \mathrm{F}^{-} \text {uptake at equilibrium represents ' } \mathrm{Q}_{\mathrm{e}} \text { ', 'b' stand for constant indicates energy of adsorption, ' } \mathrm{R}_{\mathrm{L}} \text { ' stand } \\
\text { for dimensionless equilibrium parameter, ' } \mathrm{R}^{2} \text { ' stand forregression constant, ' } \mathrm{K}_{\mathrm{f}} \text { ' stands for adsorption capability, ' } 1 / \mathrm{n}_{f} \text { ' stand for the quantity of adsorption } \\
\text { intensity. }\end{array}$} \\
\hline Kinetic adsorption Model & Linear expression & Graph & $\mathbf{R}^{2}$ & Constants & $\mathbf{Q}_{\mathrm{e}}$ \\
\hline Pseudo-first order kinetic & $\ln \left(Q_{e}-Q_{t}\right)=\ln Q_{e}-K_{1} t$ & $\ln \left(Q_{e}-Q_{t}\right) v s t$ & 0.9357 & $\mathrm{~K}_{1}=0.0351$ & 1.82 \\
\hline Pseudo-second order kinetic & $\frac{\mathrm{t}}{\mathrm{Q}_{\mathrm{t}}}=\frac{1}{\mathrm{~K}_{2} \mathrm{Qe}_{\mathrm{e}}^{2}}+\frac{1}{\mathrm{Q}_{\mathrm{e}}} \mathrm{t}$ & $\frac{\mathrm{t}}{\mathrm{Q}_{\mathrm{t}}} \mathrm{vst}$ & 0.9904 & $\mathrm{~K}_{2}=0.0419$ & 0.62 \\
\hline Intra particle diffusion & $\mathrm{Q}_{\mathrm{t}}=K_{i} t^{0.5}$ & $\mathrm{Q}_{\mathrm{tVst}}{ }^{0.5}$ & 0.9406 & $\mathrm{~K}_{\mathrm{i}}=0.0465$ & --- \\
\hline Elovich & $\mathrm{Q}_{\mathrm{t}}=\frac{1}{\beta} \ln (\alpha \beta)+\frac{1}{\beta} \ln \mathrm{t}$ & Qtvslnt & 0.9819 & $\begin{array}{l}\alpha=0.031 \\
\beta=6.734\end{array}$ & --- \\
\hline
\end{tabular}

' $\mathrm{Q}_{\mathrm{e}}$ ' and ' $\mathrm{Q}_{\mathrm{t}}$ ' stand for $\mathrm{F}^{-}$uptake at equilibrium and at a time' $\mathrm{t}$ ' ( $\left.\mathrm{min}\right)$. ' $\mathrm{k}_{1}$ ' ( $\left.\mathrm{min}^{-1}\right)$ stand for the pseudo-first-order rate constant. ' $\mathrm{k}_{2}$ ' ( $\mathrm{g}$.( $\left.\left.\mathrm{mg} / \mathrm{min}\right)^{-1}\right)$ stand for the pseudo-second-order rate constant. ' $\mathrm{k}_{\mathrm{i}}$ ' $\left(\mathrm{mg} \cdot\left(\mathrm{g} \cdot \mathrm{min}^{0.5}\right)^{-1}\right.$ stand for the intra particle diffusion rate constant. ' $\alpha$ ' $(\mathrm{mg}$. (g.min)stand for the initial adsorption rate and ' $\beta$ ' ( $\mathrm{g} / \mathrm{mg})$ stand for the surface coverage and activation energy for chemisorptions.

It is found out that the correlation coefficient $\left(\mathrm{R}^{2}=0.9904\right)$ value closure to unity and the experimentally determined ' $\mathrm{Q}$ ' value is nearer to the obtained value indicates the pseudosecond-order isotherm is a better fit. Henceforth the chemisorptionsare the rate-determining step for the $\mathrm{F}^{-}$ adsorption using AMETLC.

\subsection{Influence of temperature on Fluoride removal using AMETLC}

Temperature plays a remarkable effect on the adsorption process. In the present investigation, the removal of fluoride decreases from $92 \%$ to $76 \%$ by increasing the temperature from $25^{\circ} \mathrm{C}$ to $50^{\circ} \mathrm{C}\left(298^{\circ} \mathrm{K}\right.$ to $\left.323^{\circ} \mathrm{K}\right)$ under optimum conditions of $\mathrm{pH} 3.5$, the AMETLC dosage of $20 \mathrm{~g} \mathrm{l}^{-1}$ of AMETLC, time 50 minutes and $10 \mathrm{mg} \mathrm{l}^{-1}$ of $\mathrm{F}^{-}$solution (Figure 9). The decrease in the $\mathrm{F}^{-}$adsorption may be either an effect of increasing in the escaping tendency of fluoride ions from the AMETLC surface at higher temperatures or more solubility of $\mathrm{F}^{-}$ions in the solution. Thermodynamic studies are performed to know the reaction is exothermic or endothermic. Thermodynamic parameters are determined for temperature ranging from 298$323{ }^{\circ} \mathrm{K}\left(25-50{ }^{\circ} \mathrm{C}\right)$ by standard method [32]. It is observed that standard Gibbs free energy change $\left(\Delta \mathrm{G}^{0}\right)$ is increased by increasing temperature and hence better adsorption is attained at lower temperatures. The standard free energy $\left(\Delta \mathrm{H}^{0}\right)$ is observed as negative and the negative value of standard free energy $\left(\Delta \mathrm{H}^{0}\right)$ represents that the adsorption process is exothermic.

\subsection{Influence of co-ions on fluoride adsorption}

The co-ions such as $\mathrm{Cl}^{-}, \mathrm{NO}_{3}{ }^{-}, \mathrm{HCO}_{3}{ }^{-}, \mathrm{SO}_{4}{ }^{2-}$ and $\mathrm{PO}_{4}{ }^{3-}$ effect in the adsorption of fluoride using AMETLC as an adsorbent. The influencing of co-ions is studied by taking similar experimental procedure in which each of $10 \mathrm{mg} \mathrm{l}^{-1}$ of fluoride and chloride ions mixed and the adsorption experiment is performed under identical optimum conditions like $\mathrm{pH}$ (3.50), and the adsorbent dose is $20 \mathrm{~g} \mathrm{l}^{-1}$ of fluoride solution and time of contact 90 minutes. In this case, it is found that only $83 \%$ removal of fluoride is observed. Also, the effect of other ions like Nitrate $\left(\mathrm{NO}_{3}{ }^{-}\right)$, bicarbonate ion $\left(\mathrm{HCO}_{3}{ }^{-}\right)$, Sulphate $\left(\mathrm{SO}_{4}{ }^{2-}\right)$ and Phosphate $\left(\mathrm{PO}_{4}{ }^{3-}\right)$ ions on defluoridation has been determined similarly. Based on the results, it demonstrates that if any other co-ion present with fluoride ion, the adsorption of fluoride decreases (Table 3 ) and the influencing order is $\mathrm{PO}_{4}{ }^{3-}$ $>\mathrm{HCO}_{3}{ }^{-}>\mathrm{SO}_{4}{ }^{2-}>\mathrm{NO}_{3}{ }^{-}>\mathrm{Cl}^{-}$. The anions will compete for active sites with fluoride ion on the adsorbent and the extent of adsorption of fluoride ions on adsorbent depends on several factors [33].
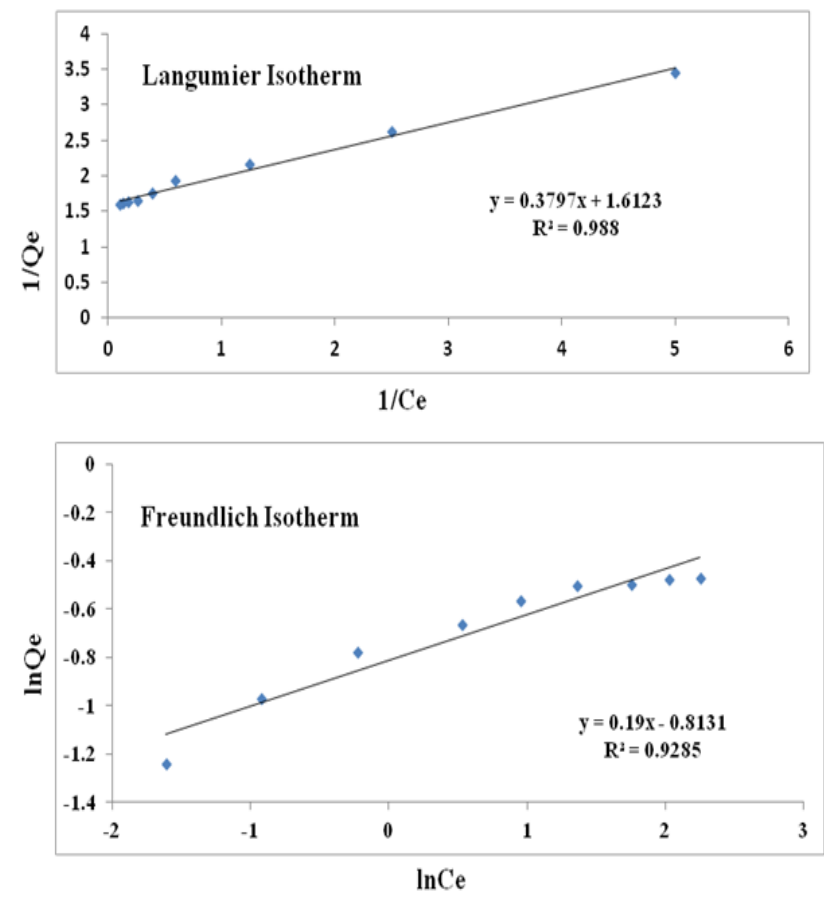

Figure 7: Langmuir and Frendlich Isotherm curves using AMETLC adsorbent 

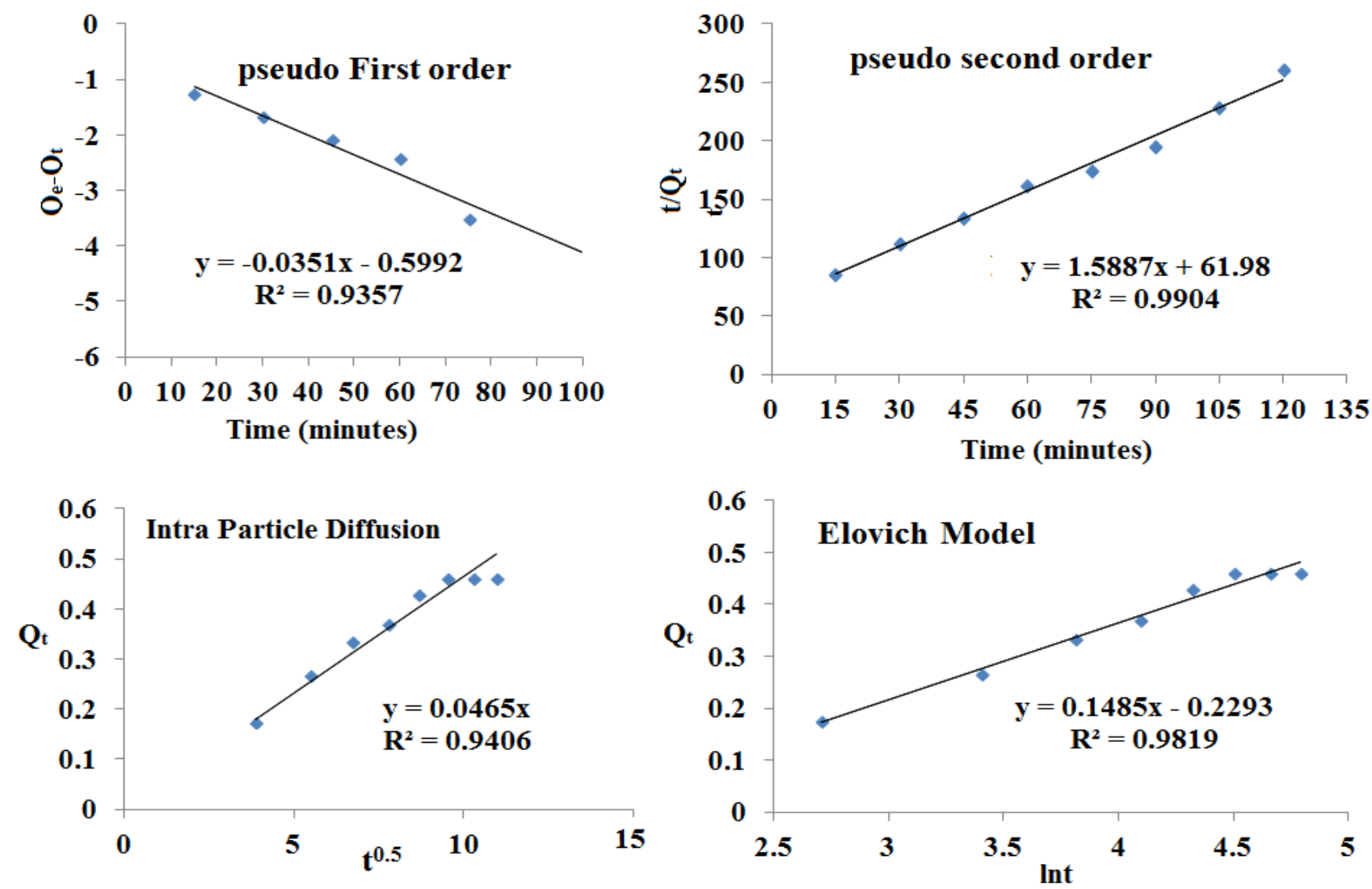

Figure 8: The kinetic study of four models for the removal of fluoride using AMETLC

Table 3: Effect of negative-ions on the removal of fluoride ion under optimum conditions

\begin{tabular}{|c|c|c|c|c|c|c|c|}
\hline \multirow[t]{2}{*}{ S. No. } & \multirow[t]{2}{*}{ Adsorbent dose } & \multirow[t]{2}{*}{$\%$ Removal of fluoride } & \multicolumn{5}{|c|}{$\%$ Removal of fluoride ion along with Co-ions } \\
\hline & & & $\mathrm{Cl}^{-}$ & $\mathrm{NO}_{3}^{-}$ & $\mathrm{SO}_{4}^{2-}$ & $\mathrm{HCO}_{3}{ }^{-}$ & $\mathrm{PO}_{4}^{3-}$ \\
\hline 1 & $20 \mathrm{~g} \mathrm{l}^{-1}$ & $92 \%$ & $83.2 \%$ & $80.7 \%$ & $72.6 \%$ & $69.1 \%$ & $67.6 \%$ \\
\hline
\end{tabular}

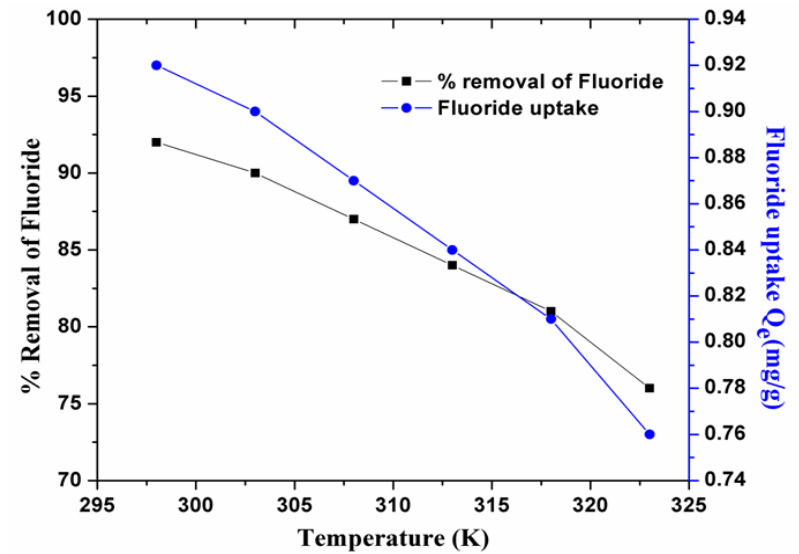

Figure 9: Effect of temperature on \% removal of fluoride and fluoride uptake $\left(\mathrm{mg} \mathrm{g}^{-1}\right)$

According to the researchers, $[34]$ the $\mathrm{Cl}^{-}$and $\mathrm{NO}_{3}{ }^{-}$ions form outer-sphere complex whereas $\mathrm{SO}_{4}{ }^{2-}$ ions can form an inner-sphere surface as well outer sphere complex. Hence sulphate $\left(\mathrm{SO}_{4}^{2-}\right)$ ion influence more than chloride and nitrate ion. The most critical factor affecting fluoride expulsion proficiency is the bicarbonate alkalinity of the water, and it diminishes the positive charge on the active sites of the adsorbent carbon, therefore, the fluoride adsorption decreases due to a decrease in the attraction of the actives sites of the adsorbing material. Phosphate ions have a more significant effect on fluoride adsorption because of its higher negative charge (inner sphere surface complex) compared to other ions.

\subsection{Examination of adsorption capability of AMETLC with different adsorbents}

A relative report has been taken for adsorption capability of various adsorbents with the present adsorbent of AMETLC. A direct correlation of AMETLC with different adsorbents is difficult due to different test conditions for different adsorbents. So by taking the adsorbent dosage, contact time, $\mathrm{pH}$ and initial fluoride concentration as optimum parameters for considering the adsorption of fluoride, a comparison is made with such adsorbents from earlier reports along with our adsorbent AMETLC and presented in Table 4. From the table, it is evident that AMETLC is one of the best alternatives for the removal of fluoride ion.

\subsection{Cost Estimation}

The leaves of Thuja Occidentalis were widely available in the underdeveloped regions and hence the activated carbon prepared from Thuja Occidentalis leaves can be utilized as a low-cost adsorbent or as a support for aluminium embedded for the adsorption of fluoride ion. In addition, succinct cost 
estimation was done for the AMETLC which offered one of the best alternatives for the removal of fluoride (since, Thuja Occidentalis leaves were gathered free of expense from study region, their expense has not been incorporated into our work. Cost of power utilization and chemicals used (Table 5) recommended our adsorbent to have cost at 19.11 US dollars per kilogram which is less than most of the available adsorbents for fluoride adsorption.

\subsection{Regeneration of fluoride loaded adsorbent}

The decontamination of water by adsorption method using adsorbent is viewed as inexpensive if the adsorbent is regenerated. Also, recycle of adsorbent decreases the natural effects of the transfer of the utilised adsorbents. Desorption of fluoride studies are done with $20 \mathrm{~g} \mathrm{l}^{-1} \mathrm{~F}^{-}$adsorbed AMETLC at different $\mathrm{pH}$ by means of $0.1 \mathrm{M} \mathrm{NaOH}$. It is observed that at $\mathrm{pH} 9.0$ onwards there is fluoride leaching occurs and a maximum of $96 \%$ fluoride leaching takes place at a $\mathrm{pH}$ of 13 . The regenerated adsorbent is utilized for the adsorption of fluoride ion from the solution with the same $10 \mathrm{mgL}^{-1}$ Fluoride concentration. The percentage removal of $\mathrm{F}^{-}$using regenerated adsorbent for several cycles is shown in Figure 10. The adsorption limit of regenerated AMETLC reduces from $92 \%$ to $78 \%$ when is used as an adsorbent for defluoridation during three cycles. However, a further study is required to assess the possibility for extended reuse of AMETLC, because the reuse of AMETLC decreases the usage of new materials for Mn(II) adsorption.

\subsection{Application of AMETLC for the removal of fluoride in groundwater samples}

The flexibility of the technique created with the novel adsorbent (AMETLC) in this work for removing $\mathrm{F}^{-}$ions has been attempted with groundwater samples taken from Gara Mandal of Srikakulam District of Andhra Pradesh. According to the BIS-2012 standards, the desirable limit of $\mathrm{F}^{-}$in drinking water is $1.0 \mathrm{mg} \mathrm{l}^{-1}$, and in the absence of an alternative source, the allowable limit is $1.5 \mathrm{mg} \mathrm{l}^{-1}$.

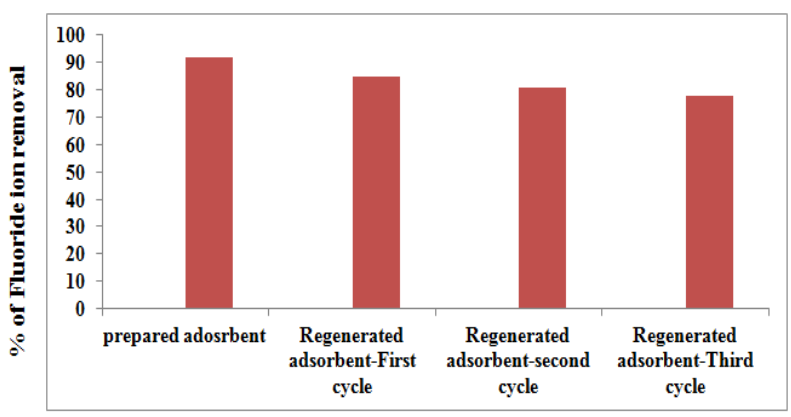

Figure 10: Removal percentage of $\mathrm{F}^{-}$from the prepared adsorbent and regenerated adsorbent of several cycles

Most of the groundwater samples having $\mathrm{F}^{-}$concentration are within the desirable limit in the study region according to BIS-2012, butsome of the water samples are exceeding than the permissible limits (i.e.1.0 $\mathrm{mg} \mathrm{l}^{-1}$ ) in the study region. Therefore, in the present study, the removal of fluoride ions from those few groundwater samples is carried out at the same optimum conditions using AMETLC adsorbent to decrease the $\mathrm{F}^{-}$content below the desirable limit. The data belongs to concentrations of $\mathrm{F}^{-}$ions in the groundwater samples before as well as after treated with AMETLC are presented in Table 6. It is proved that AMETLC sufficiently decreases the $\mathrm{F}^{-}$content in groundwater samples into the desirable limits according to BIS2012. It is understood that the methodology developed using AMETLC adsorbent for the adsorption of $\mathrm{F}^{-}$ions in this work is remarkably successful.

Table 4: Examination of fluoride uptake capability with other adsorbents

\begin{tabular}{|c|c|c|c|c|c|c|}
\hline Adsorbent & $\begin{array}{l}\text { Initial } \\
\text { F- Conc. }^{-} \text {Con }\end{array}$ & pH & $\begin{array}{l}\text { Contact } \\
\text { Time } \\
(\text { min) }\end{array}$ & $\begin{array}{l}\text { Adsorbent } \\
\text { dosage }\left(\mathrm{g} \mathrm{I}^{-1}\right)\end{array}$ & $\begin{array}{l}\text { Adsorption } \\
\text { capability (mg } \\
\left.\mathrm{g}^{-1}\right)\end{array}$ & Reference \\
\hline $\begin{array}{l}\text { zirconium ion-impregnated coconut } \\
\text { fiber carbon }\end{array}$ & 20 & 4 & 360 & 20 & 1.95 & {$[35]$} \\
\hline $\begin{array}{l}\text { Zirconium impregnated coconut } \\
\text { shell carbon }\end{array}$ & 10 & 4 & 360 & 1 & 0.99 & {$[36]$} \\
\hline $\begin{array}{l}\text { Activated carbon from Banana } \\
\text { (Musa paradisiacal) peel \& }\end{array}$ & 10 & $2 \&$ & $780 \&$ & $96 \&$ & $0.312 \&$ & {$[37]$} \\
\hline coffee (Coffea arabica) husk & & 2 & 180 & 72 & 0.2946 & \\
\hline AMETLC (Present study) & 10 & 3.5 & 90 & 20 & 0.625 & $\begin{array}{l}\text { Present } \\
\text { work }\end{array}$ \\
\hline
\end{tabular}

Table 5: Cost analysis for AMETLC

\begin{tabular}{lllll}
\hline & Duration (hours) & Unit cost (US-\$) & $\begin{array}{l}\text { Power rating } \\
(\text { KWh })\end{array}$ & Price per Kg (\$) \\
\hline Thuja Ocidentalis Leaves & - & - & - & - \\
Cost of drying process & 30 & 0.047 & 3 & 4.23 \\
Cost of activation & 5 & 0.047 & 1.2 & 0.28 \\
Cost of chemicals used & - & - & - & 14.6 \\
Total cost & & & & 19.11 \\
\hline
\end{tabular}


Table 6: The concentration of Fluoride in groundwater samples before and after adsorption using AMETLC

\begin{tabular}{lllll}
\hline $\begin{array}{l}\text { Sample } \\
\text { No. }\end{array}$ & $\begin{array}{l}\text { Water Sample collected in } \\
\text { the } \\
\text { Village }\end{array}$ & $\begin{array}{l}\text { Before adsorption of } \\
\text { fluoride(mg l-1) }\end{array}$ & $\begin{array}{l}\text { After } \\
\text { adsorption of fluoride (mg } \\
\left.\mathbf{l}^{-1}\right)\end{array}$ & $\begin{array}{l}\text { \% Removal of } \\
\text { fluoride }\end{array}$ \\
\hline 1 & Vatsavalasa & 1.2 & 0.17 & 85.8 \\
2 & Nizamabad & 1.1 & 0.19 & 82.7 \\
3 & Syrigam & 1.36 & 0.25 & 81.6 \\
4 & Ampolu & 1.4 & 0.27 & 80.7 \\
5 & Vadada & 1.1 & 0.21 & 80.9 \\
6 & Ambalavalsa & 1.12 & 0.16 & 85.7 \\
\hline
\end{tabular}

\section{Conclusions}

AMETLC is a non-toxic, reusable and promising adsorbent for the adsorption of fluoride from waste water, i.e., $92 \%$ of fluoride removal is observed at room temperature under optimum experimental conditions with an adsorbent particle size of $<75 \mu \mathrm{m}$. The co-ions for example, phosphates, sulfates, bicarbonates, nitrates and chlorides exhibit a negative impact on fluoride adsorption. The optimum $\mathrm{pH}<\mathrm{pH}_{\text {zpc }}$ of AMETLC represents that the surface of the AMETLC surface is positively charged at $\mathrm{pH}$ 3.5.FTIR examination confirmed the presence of various polar groups. SEM studies confirmed that AMETLC has shown small particles agglomerated to result in a more prominent structure with porous nature. The EDX study gives the evidence of the existence of fluorine peak after adsorption of fluoride ion using AMETLC adsorbent. XRD study reveals that the highly amorphous nature of the treated sample provides more active sites for fluoride adsorption. While the crystalline $\alpha-\mathrm{Al}_{2} \mathrm{O}_{3}, \mathrm{AlCl}_{3} \& \mathrm{Al}(\mathrm{OH})_{3}$ particles also facilitate the exchange of $\mathrm{F}^{-}$ion. The equilibrium adsorption of fluoride over the whole concentration range was best characterized by Langmuir isotherm followed by pseudo-second-order $\left(\mathrm{R}^{2}=\right.$ 0.992) model is the best fit represents that chemisorptions are the rate-determining step for fluoride removal. Thermodynamic studies reveals better adsorption is attained at lower temperatures. The standard free energy $\left(\Delta \mathrm{H}^{0}\right)$ is observed as negative and the negative value of standard free energy $\left(\Delta \mathrm{H}^{0}\right)$ represents that the adsorption process is exothermic. It is proved that AMETLC sufficiently decreases the fluoride content in groundwater samples to below the permissible limits according to BIS-2012. Hence, AMETLC is proved to be simple to prepare, no need of any precipitation step, economically feasible (since Thuja Occidentalis leaves are freely available in local region and cost of making AMETLC is far less than activated carbon accessible in the marketplace) and AMETLC is reusable for several adsorption/desorption cycles necessary for environmental friendliness for the removal of fluoride.

\section{Acknowledgment}

The authors thank the organization of the GMR Institute of Technology for giving the facilities to do this work.

\section{Competing interests}

The authors state that there is no conflict of interest that would prejudice the impartiality of this research work.

\section{Authors'contribution}

All authors of this investigation have complete involvement for adsorbent sample preparation. The corresponding author was liable for experimental data analyses. While an in-detail review was carried out by the co-authors.

\section{References}

1. Mukhtar F., Chisti H., The Study of Heavy Metals in Sediments Sampled From DalLake. Journal of EnvironmentalTreatment Techniques.6(4)(2018) 81-83.

2. Md. LokmanH., Shariful Islam K., Assessment of Water Quality in Chandpur Districtof Bangladesh.Journal of EnvironmentalTreatment Techniques. 1(2)(2013)91-100.

3. GarbaT., Yahaya Babanyara Y., Dije Bala Ibrahim., Ishaya Lot., Assessment of Underground Water Contamination Due to Early Coal Mining Activities in Nigeria. Journal of Environmental Treatment Techniques, 2(4)(2014)166-170.

4. Subba Rao N., Surya Rao P., Dinakar A., Nageswara Rao P. V., Marghade, D., Fluoride Occurrence in the Groundwater in a Coastal Region of Andhra Pradesh, India. Applied Water Science.7(2017)1467-1478.

5. Krishna KumarY., Gupta N., Vinit Kumar Khan A., Amit Kumar., A Review of Emerging Adsorbents and Current Demand for Defluoridation of Water: Bright Future in Water Sustainability.Environment International. 111(2018)80-108.

6. Jinsong He., Tiong-Shie Siah., Paul J.,Performance of an optimized Zr-based nanoparticle-embedded PSF blend hollow fiber membrane in treatment of fluoride contaminated water. Water Research.56(1)(2014)88-97.

7. Valdez-jimenez., SoriaFregozoC., Miranda M.L., Gutierrez Coronado O., PerezVegaM.I., Effects of the Fluoride on the Central Nervous System, Neurologia. 26(5)(2011)297-300.

8. Hakizimana, J.N., Gourich B., Vial Ch., Drogui P., Oumani A.,Naja J., Hilali L. Assessment of hardness, microorganism and organic matter removal from seawater by electrocoagulation as a pretreatment of desalination by reverse osmosis.Desalination.393 (2016)90-101.

9. Loganathan P., Vigneswaran S., Kandaswamy J., Naidu R., Defluoridation of drinking water using adsorption processes.Journal of Hazardous Material.248(2013)1-19.

10. Oliveira R. C., Hammer P., GuibalE., Taulemesse J. M., Garcia Jr O., Characterization of metal-biomass interactions in the lanthanum(III) biosorption on Sargassum sp. using SEM/EDX, FTIR, and XPS: Preliminary studies.Chemical Engineering Journal.239(2014)381-391.

11. Mohan D., sharma R., SinghV. K., Steele P., Charles U., Pittman Jr., Fluoride Removal from Water using Bio-Char, a Green Waste, Low-Cost Adsorbent: Equilibrium Uptake and Sorption Dynamics Modeling. Industrial and Engineering Chemistry Research.51 (2)(2012)900-914.

12. Tchomgui-Kamga E., Alonzo V., Nanseu-Njiki C.P., Audebrand N., Ngameni E., Darchen A., Preparation and characterization of charcoals that contain dispersed aluminum oxide as adsorbents for removal of fluoride from drinking water, Carbon. 48(2010)333343 .

13. Sujitha R., Ravindhranath K., Defluoridation studies using active carbon derived from the barks of Ficus racemosa plant.Journal of Fluorine Chemistry. 193(2017)58-66.

14. Singh D., Lataye H., Kailas L., Removal of Fluoride from Aqueous Solution by using Bael (Aegle Marmelos) Shell Activated Carbon: Kinetic, Equilibrium and Thermodynamic study. Journal of Fluorine Chemistry. 194(2017)23-32.

15. Palodkar A.V., Anupam K., Banerjee S., Halder G.,Insight into preparation of activated carbon towards defluoridation of waste water: Optimization, kinetics, equilibrium, and cost estimation, (2017) Published online in Wiley Online Library.

16. Mariappan R.,Vairamuthu R., Ganapathy A.,Use of chemically activated cotton nut shells carbon for the removal of fluoride 
contaminated drinking water: Kinetics evaluation.Chinese Journal of Chemical Engineering.23(4) (2015)710-721.

17. Vaishali.,Surendra PrasadT., Dinesh Kumar., Adsorptive removal of fluoride from aqueous media using Citrus limonum(lemon) leaf,Microchemical Journal.112(2014)97-103.

18. Gebrewold BD., Kijinpanich P., Rene ER., Lens PNL., Annachatri AP., Fluoride removal from groundwater using chemically modified rice husk and corn cob activated carbon.Environmental Technology. 40(22)(2018)2913-2927.

19. Shachneva E., Archibasova D., Adsorption of cadmium ions from aqueous solutions on modified sorbents, Chemistry and Chemical Technology. 12(2)(2018)182-187

20. Mondal N.K., Bhaumik R., Kumar Datta J., Removal of fluoride by aluminum impregnated coconut fiber from synthetic fluoride solution and natural water.Alexandria Engineering Journal. 54(2015)1273-1284.

21. Little E., Little Jr. Checklist of United States trees (native and naturalized). Agric. Handb. 541. Washington, DC: U.S. Department of Agriculture forest service.375(1979)2952.

22. Clebsch Edward E. C., (1989). New distributional records of arbor vitae (Thuja occidentalis L.) in the Southeast, including the written evidence for North Carolina. In: Wood, James D., Jr., compiler.Abstracts, 15th annual scientific research meeting, 1989 May 25-26; Gatlinburg, TN. Atlanta, GA: U.S. Department of the Interior, National Park Service, Southeast Regional Office: 7. Abstract. [15208].

23. Sundara kumar K., Sundara kumar P., Ratnakanth babu M.J., Hanumantha rao Ch., Assessment and mapping of ground water quality using Geographical information Systems,International Journal of Engineering Science and Technology. 2(11)(2011)6035-6046.

24. Chang LC., Song LL., Park EJ., Luvengi L., Farnsworth NR., Pezzuto JM., Kinghorn, AD.,Bioactive constituents of Thujaoccidentalis, Journal of Natural Products, 63(2000)123538.

25. Dhilleswararao V., Subbarao M.V., Muralikrishna M.P.S.,Removal of Manganese(II) from Aqueous Solution by Chemically Activated Thuja Occidentalis Leaves Carbon (CATLC) as an Adsorbent: Adsorption Equilibrium and Kinetic Studies. Physical Chemistry Research.7(1)(2019)11-26.

26. DhilleswararaoV., Subbarao M.V., Muralikrishna M.P.S.,Removal of Manganese(II) from Aqueous Solution by Chemically Activated Thuja Occidentalis Leaves Carbon (CATLC) as an Adsorbent: Adsorption Equilibrium and Kinetic Studies, Physical Chemistry Research,7(3)(2019)449-466.

27. Malairajan Singanan.,Defluoridation of Drinking Water using Metal Embedded Biocarbon Technology, International Journal of Environmental Engineering, 5(2)(2013).

28. Malwade K., LatayeD., MhaisalkarV., KurwadkarS., RamirezD., Adsorption of hexavalent chromium onto activated carbon derived from Leucaena leucocephala waste sawdust: kinetics, equilibrium and thermodynamics. International Journal of Environmental Science and Technology. 13(2016)2107-2116.

29. Rangabhashiyam S., Selvaraju N., Adsorptive remediation of hexavalent chromium from synthetic wastewater by a natural and $\mathrm{ZnCl} 2$ activated Sterculia guttata shell. Journal of Molecular Liquids. 207(2017)39-49.

30. QIAO.Junlian., CUI Zimin., SUN Yuankui., HU Qinghai., XiaohongG.,Simultaneous removal of arsenate and fluoride from water by $\mathrm{Al}-\mathrm{Fe}$ (hydr)oxides, Frontiers of Environmental Science \& Engineering,8(2)(2014)169-179.

31. Masoud M.S., El-Saraf W.M., Abdel-HalimA.M., Ali A.E., Mohamed E.A., Hasan H.M.I., Rice husk and activated carbon for waste water treatment of El-Mex Bay, Alexandria Coast, Egypt, Arabian Journal of Chemistry, 9(2016)1590-1596.

32. Mustapha S.,Ndamitso M. M., Mohammed U. M., Adeosun N. O., Idris M., Study on Activated from Melon (Citrullus lanatus) Husk as Natural Adsorbent for Removal of Hardness in Water.Advances in Analytical Chemistry. 6(1)(2016) 1-9.

33. Onyango M.S., Kojima Y., Aoyi O., Bernardo E.C., Matsuda H.,Adsorption equilibrium modeling and solution chemistry dependence of fluoride removal from water by trivalent-cationexchanged zeolite. Journal of Colloid and Interface Science.279 (2004)341-350.
34. Zhang P.C., Spark D.L., Kinetics and Mechanisms of Sulfate Adsorption/Desorption on Goethite Using Pressure- Jump Relaxation, Soil Science Society of America journal.54(1990)1266-1273.

35. Sai Sathish R., Sairam S., Guru Raja V., Nageswara Rao G., Janardhana C., Defluoridation of Water Using Zirconium Impregnated Coconut Fiber Carbon, Separation Science and Technology.3(2008)3676-3694.

36. Sai Sathish R.,Raju N.S.R., Raju G.S., Nageswara Rao G., Anil Kumar K., Janardhana C., Equilibrium and kinetic studies for fluoride adsorption from water on zirconium impregnated coconut shell carbon, Separation Science and Technology. 42(2007)769788 .

37. Getachew T., Hussen A., Rao V.M., Defluoridation of Water by Activated Carbon Prepared from Banana (Musa paradisiaca) Peel and Coffee (Coffea arabica) Husk, International Journal of Environmental Science and Technology.12(2014)1857-1866. 